\title{
MANAJEMEN KEPALA SEKOLAH DALAM MENERAPKAN BUDAYA RELIGIUS DI SMA NEGERI 2 SIJUNJUNG
}

\author{
Zulhendri \\ Nagari Tanjung Gadang Kecamatan Tanjung Gadang Kabupaten Sijunjung \\ e-mail: hendriz498@gmail.com \\ Asogen
}

\begin{abstract}
This study aims to describe the form of religious culture applied in SMA Negeri 2 Sijunjung and how the principal in implementing religious culture. The type of research used is qualitative descriptive. Informant research as many as 8 people. Data collection tools are researchers as key instruments and supporting instruments are interview guides, observation guides, field notes, and hp. Data collection techniques are participatory observation, in-depth interview and documentation study. Data analysis technique using Spradley (1980) model is doing domain analysis, carrying out taxonomic analysis, doing component analysis and doing theme analysis. Techniques of testing the validity of data using triangulation of data and methods. The results showed that starting planning, organizing, implementing and supervising religious programs such as Zubr prayers in congregation, zikir and prayer, tadarrus al-qur'an, culture 5S, and infake and gebu program applied in SMA Negeri 2 Sijunjung, head the school always involves all the citizens of the school ranging from teachers, education personnel, school committees, and security guards. It is implemented by the school principal and the whole school community through chanting, babituation, giving advice (motivation), and the commemoration of Islamic day (PHBI). So that these religious activities can run well in SMA Negeri 2 Sijunjung.
\end{abstract}

Keywords: manajemen, kepala sekolah, budaya religius

\section{PENDAHULAN}

Pendidikan sangat penting bagi kehidupan manusia, sebab melalui pendidikan segenap potensi yang dimiliki manusia termasuk ilmu pengetahuan akan dapat dikembangkan. Oleh sebab itu manusia disuruh untuk menuntut ilmu pengetahuan tersebut. Sebagaimana firman Allah SWT dalam surat $\mathrm{Al}$ - Mujadalah ayat 11:

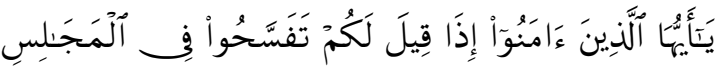

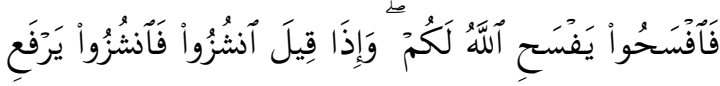

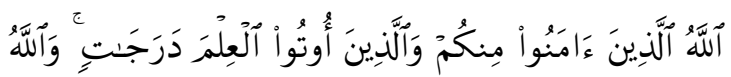

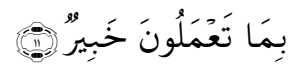

Niscaya Allah akan memberi kelapangan untukmu. dan apabila dikatakan: "Berdirilah kamu", Maka berdirilah, niscaya Allah akan meninggikan orang-orang yang beriman di antaramu dan orang-orang yang diberi ilmu pengetahuan beberapa derajat. dan Allab Maha mengetabui apa yang kamu kerjakan. (Departemen Agama RI, (2007) 
Surat al-Mujadalah menjelaskan tentang keutamaan orang-orang beriman dan berilmu pengetahuan, bahwa ayat ini menegaskan bahwa orang beriman dan berilmu pengetahuan akan diangkat derajatnya oleh Allah SWT. Akan tetapi perlu diingat orang beriman, tetapi tidak berilmu dia akan lemah oleh karena itu keimanan seseorang yang tidak didasari atas ilmu pengetahuan tidak akan kuat. Begitu juga sebaliknya orang berilmu tetapi tidak beriman ia akan tersesat.

Pendidikan adalah usaha sadar dan bertujuan untuk mengembangkan kualitas manusia. Sebagai suatu kegiatan yang sadar akan tujuan, maka dalam pelaksanaannya berada dalam suatu proses yang berkesinambungan dalam setiap jenis dan jenjang pendidikan, semuanya berkaitan dalam suatu sistem pendidikan yang integral. Pendidikan sebagai suatu sistem, tidak lain dari suatu totalitas fungsional yang terarah pada suatu tujuan. Suatu sub sistem yang ada dalam sistem tersusun dan tidak dapat dipisahkan dari unsur-unsur atau komponen yang berhubungan secara dinamis dalam suatu kesatuan.

Pendidikan menurut Undang- undang No. 20 tahun 2003 bab I pasal 1 adalah usaha sadar dan terencana untuk mewujudkan suasana belajar dan proses pembelajaran agar peserta didik secara aktif mengembangkan potensi dirinya untuk memiliki kekuatan spiritual keagamaan, pengendalian diri, kepribadian, kecerdasan, akhlak mulia, serta keterampilan yang diperlukan dirinya, masyarakat, bangsa dan negara (Departemen Agama RI, 2006: 5)

Sedangkan pendidikan nasional adalah pendidikan yang berdasarkan pancasila dan Undang-Undang Dasar Nagara Republik
Indonesia Tahun 1945 yang berakar pada nilai-nilai agama, kebudayaan Indonesia nasional Indonesia dan tanggapan terhadap tuntutan perubahan zaman (Departemen Agama RI, 2006: 5)

Fungsi pendidikan nasional adalah mengembangkan kemampuan dan membentuk watak serta peradaban bangsa yang bermartabat dalam rangka mencerdaskan kehidupan bangsa. Sedangkan tujuan pendidikan nasional adalah untuk mengembangkan potensi peserta didik agar menjadi manusia yang beriman dan bertaqwa kepada Tuhan yang Maha Esa, beraklak mulia, sehat, cakap, kreatif, mandiri, dan menjadi warga negara yang demokratis, serta bertanggung Jawab. (Departemen Agama RI, 2006: 5)

Pendidikan Islam adalah bimbingan yang dilakukan oleh seorang dewasa kepada terdidik dalam masa pertumbuhan agar ia memiliki kepribadian muslim. Oleh karena itu pendidikan Islam adalah sekaligus pendidikan iman dan pendidikan amal. Karena pendidikan Islam berisi sikap dan tingkah laku pribadi dalam masyarakat, menuju kesejahteraan hidup baik secara individual maupun kelompok, maka orang yang pertama yang mendidik dalam masyarakat adalah Nabi dan Rasul dan diteruskan oleh para ulama segabai penerus tugas dan kewajiban mereka.

Salah satu unsur terpenting dalam proses pendidikan adalah pendidik dan peserta didik. Pendidik dan peserta didik adalah dua sosok manusia yang tidak dapat dipisahkan dari dunia pendidikan. Peserta didik adalah setiap orang yang menerima pengaruh dari seseorang atau sekelompok orang yang menjalankan kegiatan pendidikan, pendidik tidak berarti apa-apa tanpa kehadiran peserta didik sebagai subjek 
pembinaan. Jadi peserta didik adalah kunci terjadinya interaksi edukatif.

Hasibuan, mendefenisikan manajemen adalah ilmu dan seni yang mengatur proses pemanfaatan sumber daya manusia dan sumber-sumber lainnya secara efektif dan efisien untuk mencapai suatu tujuan tertentu. (Malayu S.P Hasibuan, 1990: 3) Sedangkan menurut Terry yang dikutip oleh Hasibuan, (2006) mengartikan manajemen merupakan suatu proses yang terdiri dari tindakan-tindakan perencanaan, pengorganisasian, menggerakkan, dan mengendalikan, yang dilakukan untuk menentukan serta mencapai sasaran yang telah ditentukan melalui pemanfaatan sumber daya manusia dan sumber daya lainnya.

Kepala sekolah merupakan pejabat profesional dalam mengelola organisasi sekolah sekaligus bertugas mengatur dan mengelola semua sumber, organisasi dan bekerjasama dengan komite sekolah, masyarakat, lembaga-lembaga lain serta stakeholder yang ada. Kepeminpinan kepala sekolah dalam mengembangkan dan mengelola sekolah harus memahami kebutuhan sekolah yang dipimpinnya termasuk kebutuhan guru, murid dan warga sekolah. Kepala sekolah profesional akan selalu memberi motivasi seluruh komponen sekolah untuk meningkatkan kompetensinya sehingga kompetensi warga sekolah dapat meningkat dan berkembang baik. Kepala sekolah dan guru sebagai tenaga kependidikan yang profesional tidak hanya menguasai bidang ilmu, bahan ajar, dan metode, akan tetapi mampu memotivasi peserta didik untuk memiliki keterampilan dan wawasan luas terhadap pendidikan.

Kepala sekolah adalah jabatan yang tidak bisa diisi oleh orang-orang tanpa didasarkan atas pertimbangan-pertimbangan.
Siapa pun yang akan diangkat menjadi kepala sekolah harus ditentukan melalui prosedur serta persyaratan-persyaratan tertentu seperti: latar belakang pendidikan, pengalaman, usia, pangkat, dan integritas. (Wahjosumidjo, 2011: 84)

Budaya religius dalam suatu lembaga pendidikan sangat perlu ditekankan, sekalipun itu lembaga pendidikan berbasis Islam. Karena budaya religius adalah sekumpulan nilai agama yang melandasi perilaku, tradisi, kebiasaan, dan simbolsimbol yang dipraktikkan guru sebagai tenaga pendidik di madrasah. Budaya religius merupakan cara berfikir dan bertindak warga sekolah yang didasari atas nilai-nilai religius (keberagaman). (Asmaun Sahlan, 2009: 75)

Berdasarkan pengamatan awal yang penulis lakukan bahwa di SMA Negeri 2 Sijunjung tersebut terlihat fenomenafenomena diantaranya yang penulis lihat adalah sebagai berikut: (1) jumlah siswa yang masuk ke SMA Negeri 2 Sijunjung setiap tahun meningkat, tahun 2015/2016 jumlah siswa 197 orang, 2016/2017 jumlah siswa 215 orang, dan 2017/2018 jumlah siswa 226. (2) prestasi siswanya bagus sekali baik akdemik maupun non akademik ini peneliti lihat banyaknya penghargaan-penghargaan yang diperoleh siswa setiap tahun berupa piala, medali dan piagam, (3) banyaknya guru yang berprestasi dan berpendidikan magister (S2), (4) warga SMA Negeri 2 Sijunjung selalu menjaga kebersamaan antara kepala sekolah dengan guru, guru dengan siswa dan seluruh warga sekolah, (5) seluruh warga SMA Negeri 2 Sijunjung religius sangat baik hal ini terlihat seluruh program keagamaan berjalan dengan baik. (Observasi awal, Selasa 3 Mei 2017). 


\section{KA IANTEORI}

\section{Konsep Manajemen}

Kata manajemen berasal dari bahasa latin, yaitu kata manus dan agree yang berarti melakukan kata itu digabung menjadi kata kerja managere yang artinya menangani. Managere diterjemahkan dalam bahasa inggris dalam bentuk kata kerja to manage, dengan kata bendanya management, dan manajer untuk orang yang melakukan manajemen. Akhirnya manajemen diterjemahkan dalam bahasa Indonesia menjadi manajemen atau pengelolaan. (Husaini Usman, 2008: 3) Hasibuan, mendefenisikan manajemen adalah ilmu dan seni yang mengatur proses pemanfaatan sumber daya manusia dan sumber-sumber lainnya secara efektif dan efisien untuk mencapai suatu tujuan tertentu. (Malayu S.P Hasibuan, 1990: 3) Sedangkan menurut Terry yang dikutip oleh Hasibuan, (2006) mengartikan manajemen merupakan suatu proses yang terdiri dari tindakantindakan perencanaan, pengorganisasian, menggerakkan, dan mengendalikan, yang dilakukan untuk menentukan serta mencapai sasaran yang telah ditentukan melalui pemanfaatan sumber daya manusia dan sumber daya lainnya.

Berkaitan dengan itu, terdapat 3 pendapat berbeda; pertama mengartikan lebih luas dari pada manajemen (manajemen merupakan inti dari admistrasi); kedua, melihat manajemen lebih luas dari pada administrasi dan ketiga, pandangan yang menggangap bahwa manajemen identik dengan administrasi. Berdasarkan fungsi pokoknya istilah manajemen dan administrasi menpunyai fungsi yang sama karena itu perbedaan kedua istilah tersebut

48 Jurnal al-Fikrah, Vol. VI, No. 1 Januari-Juni 2018 tidak konsisten dan tidak signifikan. (E Mulyasa, 2012: 19)

\section{Manajemen Kepala Sekolah}

Manajerial kepala sekolah berhubungan erat dengan keutuhan dan eksistensi sekolah, berusaha memahami kondisi tenaga pendidik dan kependidikan. Dalam menjalankan tugas tersebut ia tidak bisa mewujudkan tujuannya apabila kondisi kerja para guru tidak tertata dengan baik. Wahjosumidjo, (2011) mengemukan pengertian kepala sekolah adalah sebagai seorang tenaga profesional guru yang diberi tugas untuk memimpin suatu sekoalah dimana diselenggarakan proses belajar mengajar atau tempat dimana terjadi interaksi antara yang memberikan pelajaran dan murid yang menerima pelajaran. Sementara Rahman dkk dalam Asmendri, (2012) mengungkapkan bahwa kepala sekolah adalah seorang guru (jabatan fungsional) yang diangkat untuk menduduki jabatan struktural (kepala sekolah) di sekolah. Berdasarkan beberapa pengertian di atas dapat disimpulkan bahwa kepala sekolah adalah seorang guru yang mempunyai kemampuan untuk memimpin segala sumber daya yang ada di sekolah, sehingga dapatdidayagunakan secara maksimal untuk mencapai tujuan bersama.

\section{Budaya Religius}

Bentuk jamak dari budaya adalah kebudayaan berasal dari bahasa sansekerta budhayah yang merupakan bentuk jamak dari budi, yang artinnya akal atau segala sesuatu yang berhubungan dengan akal pikiran dan budi manusia. Istilah "budaya" mula-mula dating dari disiplin ilmu Antropologi Sosial. Apa yang tercakup 
dalam definisi budaya sangatlah luas. Istilah budaya dapat diartikan sebagai totalitas pola perilaku, kesenian, kepercayaan, kelembagaan, dan semua produk lain dari karya dan pemikiran manusia yang mencirikan suatu masyarakat atau penduduk yang ditransmisikan bersama. (Sahlan, 2012). Dari berbagai definisi tersebut, dapat diperoleh pengertian bahwa budaya adalah suatu sitem pengetahuan yang meliputi sistem ide atau gagasan yang terdapat dalam pikiran manusia, sehingga dalam segari-hari bersifat abstrak. Sedangkan perwujudannya ialah berupa perilaku, dan benda-benda yang bersifat nyata yakni, pola prilaku, bahasa, organisasi sosial, religi, seni, dan lainlain.Yang kesemuannya ditunjuk untuk membantu manusia dalam melangsungkan kehidupan bermasyarakatnya. Budaya religius dalam suatu lembaga pendidikan sangat perlu ditekankan, sekalipun itu lembaga pendidikan berbasis Islam. Karena budaya religius adalah sekumpulan nilai agama yang melandasi perilaku, tradisi, kebiasaan, dan simbol-simbol yang dipraktikkan guru sebagai tenaga pendidik di madrasah. Budaya religius merupakan cara berfikir dan bertindak warga sekolah yang didasari atas nilai-nilai religius (keberagaman). (Sahlan, 2009: 75)

\section{METODE PENEUTAN}

Jenis pendekatan dalam penelitian ini adalah Kualitatif Deskriptif, di mana peneliti melakukan penelitian di SMA Negeri 2 Sijunjung tentang manajemen kepala sekolah dalam menerapkan budaya religius. Penelitian ini juga bermaksud mengambarkan dan mengamati prilaku dan budaya warga sekolah dalam kegiatan sehari-hari sehubungan dengan budaya religius. yaitu penelitian yang dimaksudkan untuk menyimpulkan informasi mengenai setatus gejala yang ada, yaitu gejala menurut apa yang ada pada saat penelitian dilakukan. (Suharsimi Arikunto, 2010: 234)

Instrumen penelitian adalah peneliti sendiri yang menjadi instrumen kunci atau utama yang mengumpulkan data berdasarkan kriteria-kriteria yang dipahami. Instrumen pendukung pada penelitian ini adalah mengunakan pedoman observasi dan pedoman wawancara serta alat lainnya. Sumber data dalam penelitian ini ada 8 orang dengan mengunakan teknik pengumpulan data yaitu: observasi, wawancara dan dokumentasi.

Teknik analisis data dalam penelitian ini mengunakan model yang dilakukan oleh Spradley dalam Sugiyono, (2012) membagi analisis data dalam penelitian kualitatif berdasarkan tahap - tahap sebagai berikut:

1. Analisis domain yaitu: memperoleh gambaran yang umum dan menyeluruh dari objek penelitian atau situasi sosial

2. Analisis Taksonomi yaitu: domain yang dipilih tersebut selanjutnya dijabarkan menjadi lebih rinci, untuk mengetahui struktur internalnya.

3. Analisis komponensial yaitu: mencari ciri spesifik pada setiap struktur internal dengan cara mengekontraskan antar elemen.

4. Analisis tema kultural yaitu: mencari hubungan di antara domain, dan bagaimana hubungan dengan keseluruhan, dan selanjutnya dinyatakan ke dalam tema atau judul penelitian.

Dalam tahapannya peneliti menggambarkan seluruh domain yang terkait dengan objek penelitian tentang sarana dan prasarana, program pembelajaran, program 
religius atau keagamaan dan lingkungan sekolah, setelah itu peneliti menjabarkan secara rinci salah satu objek dan melihat speksifiknya, kemudian baru dicari hubungan antara domaian satu dengan yang lainnya. Pengolahan data dalam penelitian ini adalah secara kualitatif yaitu mengungkapkan dan mengambarkan kejadian-kejadian, fenomena-fenomena, dan fakta-fakta yang terjadi di lapangan sebagaimana adanya. Di sini penulis mengolah hasil observasi dan wawancara yang telah dilakukan sehingga penulis dapat mengambarkan manajemen kepala sekolah dalam menerapkan budaya religius di SMA Negeri 2 Sijunjung.

\section{HASIL DANPEMBAHASAN}

\section{Bentuk Budaya religius di SMA Negeri 2 Sijunjung}

Dalam mengembangkan budaya religius di SMA Negeri 2 Sijunjung merupakan bagian dari tahapan pelaksanaan manajemen kepala sekolah yang telah disetujui bersama oleh pihak sekolah, menurut Rohiat bahwasanya kepala sekolah dan guru bebas mengambil inisiatif dan kreatif dalam menjalankan programprogram yang proyeksikan hingga mencapai sasaran yang telah ditetapan. Maka setelah kepala sekolah menuangkan kebijakannya dalam mengembangkan budaya religius, sesuai dengan teori Asmaun agar dapat terlaksana dengan baik diperlukan keteladanan dan pembiasaan. Seperti yang diungkapkan oleh Bapak Drs. Syafaruddin, MM selaku kepala sekolah di SMA Negeri 2 Sijunjung sebagai berikut:

"Untuk menjadikan siswa agar terbiasa, jadi sebuah pembiasaan dalam rangka menjalankan nilai-nilai keagamaan maka perlu adanya pembiasaan disiplin dan sopan santun, budaya senyum, salam dan sapa. Dan setiap hari siswa dibiasakan shalat zuhur berjema'ah, membaca dzikir sesudah shalat asma'ul husna, dan membaca al-Qur'an, serta mengumpulkan infak dan setiap jum'at pagi kultum yaitu kultum Jum'at'. (Syafaruddin: 27/7/2017)

Ungkapan di atas didukung oleh pernyataan Bapak Wirman sebagai kepala tata usaha di SMA Negeri 2 Sijunjung, beliau mengatakan bahwa:

"Keagamaan di SMA ini sangat efektif, pandangan saya sebagai kepala tata usaha dalam program keagamaan sangat lah baik. Diantaranya program keagamaan di SMA 2 Sijunjung ini yaitu berupa, seperti: shalat zuhur berjamaah, baca al-qur'an dan lomba-lomba kaligrafi, kemudian peringatan-peringatan hari besar Islam dan lomba-lomba keagamaan seperti: nasyid, pembacaan asma'ul husna" (Wirman: 4/1/2018)

\section{Cara Menerapkan Budaya Religius di SMA Negeri 2 Sijunjung}

Budaya religius yang diterapkan di SMA Negeri 2 Sijunjung yaitu, shalat zuhur berjema'ah, zikir dan do'a setelah shalat, budaya 5S, tadarrus al-qur'an, serta infak setiap hari kamis. Hal ini sudah dijalankan oleh siswa dalam kehidupan sehari-hari. Untuk menerapkan budaya religius tersebut perlu adanya cara atau upaya tertentu dari kepala sekolah. Dari hasil wawancara dan pengamatan peneliti, ada beberapa cara yang dilakukan kepada sekolah SMA Negeri 2 Sijunjung sebagai berikut:

50 Jurnal al-Fikrah, Vol. VI, №. 1 Januari-Juni 2018 
1) Ketauladanan

Menurut pengamatan peneliti pendekatan ketaudanan yang dilakukan oleh guru SMA Negeri 2 Sijunjung dalam menerapkan budaya religius pada siswa adalah dengan memberikan contoh baik ucapan ucapan dan perbuatan hal ini sesuai dengan pendapat kepala sekolah Bapak Drs. Syafaruddin, MM bahwa:

"Jadi Rasul kita menegur kan sebaiksebaik teguran adalah dengan memberi contoh jadi kita prinsip keteladanan ya karna guru yang ditua kan sebagai orang tua yaitu memberikan keteladanan baik dalam perkataan dan perbuatan jadi dengan contoh ini nantik anak akan mudah untuk mengaplikasikan" (Syafaruddin: 27/7/2017)

Dan hal ini senada dengan pendapat waka kesiswaan Ibuk Emi Siti Amanah, S.Pd.I yang menyatakan bahwa:

"Kalau ketauladanan itu menurut saya kita harus mencontohkan kepada anakanak, contohnya seperti shalat zuhur berjamaah di mushalla, baru membaca alqur'an tadi, infak" (Emi Siti Amanah: $8 / 8 / 2017$ )

Hal ini juga diperkuat oleh Bapak Zainal, S.Pd selaku waka kurikulum mengatakan bahwa:

"Jadi kalau untuk keseluruhannya kita terapkan di sekolah melalui ketauladanan dengan banyaknya guru ke mushalla semakin termotivasi siswa untuk ke mashalla untuk melakukan shalat berjamaah" (Zainal: 31/7/2017)

Berdasarkan pengamatan peneliti secara bekesinambungan peneliti melihat dengan ketauladanan yang dicontohkan oleh seluruh warga sekolah penerapan budaya religius di SMA Negeri 2 Sijunjung dapat berjalan dengan baik.

2) Pembiasaan

Dengan adanya pembiasaan ketika melaksanakan kegiatan tujuannya untuk dijalankan suatu langkah membina akhlak siswa, seperti yang diungkapkan oleh Bapak Drs. Syafaruddin, MM, selaku kepala sekolah di SMA Negeri 2 Sijunjung menyatakan bahwa:

"Pembiasaan, contoh pembiasaan bersalaman dengan membaca salam tadi, dengan konsep 5S tadi merupakan sebuah pembiasaan, kemudian pembiasaan shalat zuhur berjamaah, pembiasaan disiplin sehingga terbentuk karakter yang sesuai dengan akhlakul karima" (Syafaruddin: $27 / 7 / 2017$ )

Hal ini di dukung oleh ungkapan Ibuk Rukmini, M.Pd selaku waka sarana di SMA Negeri 2 Sijunjung yang menyatakan bahwa: "Untuk membiasakan anak-anak itu shalat berjamaah kemudian zikir, baca alqur'an selasa, kamis, sabtu itu baca literasi atau buku-buku yang bermanfaat. Jadi shalat berjamaah ini diadakan setiap hari dengan kebiasaan setiap hari kita lakukan maka anak ini akan tertanam di dalam jiwa suatu pendekatan kepada Allah, bak pepatah minang ketek ta aja-aja gadang taraja-raja la gaek ndak ta ubah. Jadi dengan adanya shalat berjamaah secara rutin dilaksanakan dengan sendiri akan terasa mendalam bagi anak kita" (Rukmini: 1/8/2017)

Hal ini di dukung oleh ungkapan Ibuk Emi Siti Amanah, S.Pd.I selaku waka kesiswaan di SMA Negeri 2 Sijunjung yang menyatakan bahwa: 
"Pembiasaannya di mulai dari guru biasanya, untuk anak-anak dalam penerapan contohnya peraturan-peraturan di sekolah, setiap paginya baca asma'ul husna dulu, baca do'a dulu sebelum belajar" (Emi Siti Amanah: 8/8/2017

Berdasarkan pengamatan peneliti secara bekesinambungan peneliti melihat dengan cara pembiasaan dan mengkondisikan kebiasaan siswa dalam mempraktikkan ibadah keagamaan, yang dimulai dari kepala sekolah, guru, dan oleh seluruh warga sekolah dalam menerapkan budaya religius di SMA Negeri 2 Sijunjung, dengan sendirinya siswa akan menyadari tentang pentingnya ibadah dalam kehidupan sehari-hari.

3) Pemberian Nasehat (Manidzab)

Pemberian nasehat merupakan salah cara menerapkan budaya religius di SMA Negeri 2 sijunjung. Hal ini sesuai dengan hasil wawancara peneliti dengan Bapak Drs. Syafaruddin, MM mengatakan bahwa:

"Kemudian nasehat atau memberi nasehat karna dengan nasehat itu akan lama habisnya jika lau uang kita berikan pada anak mungkin akan cepat habisnya tetapi kalau nasehat bertahan lama, terus ya memberikan motivasi ya dorongan kita konsep kan bagaimana kita di depan bisa memberikan contoh tengah-tengah kita memberikan apa apa namanya ima dia mangunkaso, kan membangunkan dibelakang bisa memberikan dorongan dengan baik" (Syafaruddin: 27/7/2017)

Sedangkan menurut Ibu Emi Siti Amanah selaku waka kesiswaan di SMA Negeri 2 Sijunjung mengatakan bahwa:

"Kalau motivasi itu sangat penting, karna kita harus memotivasi anak-anak itu supaya anak-anak bisa paham dan mengerti apa-apa saja yang kita terapkan di sekolah ini, contohnya kalau dalam pendidikan agama Islam seperti kita shalat berjamaah tadi, kita selalu memotivasi anak kita supaya rajin shalat berjamaah di mushalla" (Emi Siti Amanah: 8/8/2017)

Dari paparan yang disampai oleh infoman di atas dapat peneliti tarik kesimpulan bahwa pemberian nasehat sangat baik digunakan dalam menerapkan budaya religius, kerana kepala sekolah dan guru dapat mengarahkan siswa kepada kebaikan yang terdapat dalam syariat Islam.

4) Peringatan Hari Besar Islam (PHBI)

Kegiatan PHBI yang diadakan di SMA Negeri 2 Sijunjung adalah peringatan tahun baru Islam (1 Muharram), Maulid Nabi (12 Rabiul awal), Isra' Mijra' (27 Rajab), serta serta mengisi bulan ramadhan dengan mengadakan pesantren ramadhan. Hal ini sesuai dengan ungkapan yang disampaikan oleh Bapak Drs. Syafaruddin, MM selaku kepala sekolah di SMA Negeri 2 Sijunjung, sebagai berikut:

"Dengan selalu memperingati hari besarbesar Islam seperti: isra' miraj, maulid nabi, nuzul al-qur'an dan hari-hari besar Islam lainnya, dan mayoritas siswa kita Islam, dan semuanya kita lakukan di mesjid, tujuan kita adalah bagaimana mereka mencintai Allah, mencintai Rasul dan mencintai mesjid karna mesjid adalah tempat segala-galanya" (Syafaruddin: 27/7/2017)

Hal ini juga ungkapan oleh Ibuk Rezi Afriza, S.Pd.I selaku guru Agama di SMA Negeri 2 Sijunjung, sebagai berikut: 
"PHBI ini adalah kegiatan untuk memperingati hari besar Islam, dengan maksud syiar Islam sekaligus menggali arti dan makna dari suatu hari besar Islam. Karena didalam setiap perayaan hari besar Islam selalu ada cerita luar biasa yang patut diketahui oleh kaum muslim, dan ini sangat baik sekali untuk diajarkan kepada para siswa SMA Negeri 2 Sijunjung" (Rezi Afriza: 3/8/2017)

Hal ini juga di dukung oleh ungkapan Ibuk Rukmini, S.Pd.I selaku waka sarana SMA Negeri 2 Sijunjung, yang menyatakan bahwa:

"Setiap peringatan hari besar Islam itu mengadakan tabligh akbar kemudian mengadakan lomba kaligrafi, lomba azan dan lomba hafiz" (Rukmini: 1/8/2017)

Dapat peneliti simpulkan bahwa melalui peringatan-peringatan hari besar Islam atau kajian-kajian keagamaan baik digunakan untuk ciptakan budaya religius di sekolah. Karena setiap peringatan hari besar Islam tersebut mempunyai pelajaranpelajaran agama yang dapat diterapkan dalam kehidupan sehari-hari.

\section{Pembahasan}

Manajemen kepala sekolah dalam menerapkan budaya religius di SMA Negeri 2 Sijunjung adalah sebagai berikut:

a. Ketauladanan

Dalam kamus besar bahasa Indonesia disebutkan keteladanan dari kata "teladan" yaitu perbuatan atau barang, yang patut ditiru dan dicontoh. Oleh karena itu keteladanan adalah hal hal yang dapat ditiru atau dicontoh. Dalam bahasa Arab keteladanan diungkapkan dengan kata "uswah" yang berarti pengobatan. Dengan demikian keteladanan adalah hal-hal yang dapat ditiu atau dicontoh oleh seseorang dari orang lain. Namun keteladanan yang dimaksud di sini adalah keteladanan yang dapat dijadikan sebagai alat pendidikan Islam, yaitu keteladanan yang baik.

b. Pembiasaan

Pembiasaan adalah salah satu alat pendidikan yang penting sekali, oleh karena itu sebagai permulaan dan sebagai pangkal pendidikan pembiasaan merupakan alat satu-satunya. Sejak dilahirkan anak-anak harus dilatih dengan kebiasankebiasaan dan perbuatan-perbuatan yang baik. anak-anak dapat menurut dan taat kepada peraturan-peraturan yang baik, di dalam rumah tangga atau keluarga, di sekolah dan juga tempat lain.

c. berian Nasehat (Manidzab)

Menurut Rasyid Ridla, mauidzah adalah nasehat peringatan atas kebaikan dan kebenaran dengan jalan apa yang dapat meneyentuh hati dan membangkitkannya untuk mengamalkannya Metode manidzah, harus mengandung tiga unsur, yakni: uraian tentang kebaikan dan kebenaran yang harus dilakukan oleh seorang, dalam hal ini santi, misalnya tentang sopan santun, harus berjamaah maupun kerajinan dalam beramal, motivasi dalam melakukan kebaikan, dan peringatan tentang dosa atau bahaya. Peringatana Hari Besar Islam (PHBI). Kegiatan Peringatan Hari Besar Islam (PHBI), seperti: peringatan 1 Muharram, Maulid Nabi Muhammad SAW, peringatan Isra' Mi'raj Nabi Muhammad SAW, serta mengisi bulan ramadhan dengan mengadakan pesantren Ramadhan. Itu merupakan salah satu bentuk upaya kepala sekolah dalam memperingati peristiwa sejarah yang penuh makna, sekaligus untuk menanamkan pribadi yang religius terhadap siswa. 


\section{PENUTUP}

\section{Kesimpulan}

Setelah melakukan kajian teoritis dan analisis data berdasarkan temuan di lapangan mengenai Manajemen Kepala Sekolah dalam Menerapkan Budaya Religius di SMA Negeri 2 Sijunjung, maka dapat disimpulkan sebagai berikut: shalat Zuhur berjema'ah merupakan salah satu budaya religius yang diterapkan di SMA Negeri 2 Sijunjung, seluruh warga sekolah menuju ke mushollah ketika waktu shalat Zuhur hampir masuk untuk melaksanakan shalat Zuhur berjema'ah, do'a dan zikir merupakan budaya religius yang telah diterapkan di SMA Negeri 2 Sijunjung, yang dilaksanakan setelah shalat Zuhur dengan tujuan untuk mengingat Allah SWT dan memohon segala sesuatu kedapa Allah SWT melalui do'a-do'a yang disampaikan, tadarrus Al-qur'an atau kegiatan membaca dilaksanakan pada setiap kamis, jum'at dan sabtu sebelum memulai proses pembelajaran di kelas masing-masing, sikap (senyum, salam, sapa, sopan, dan satun) seorang muslim dianjurkan untuk saling menyapa satu sama lain ketika bertemu, dan bentuk sapaannya adalah mengucapkan salam, dan infak setiap hari kamis dan gebu ini merupakan budaya religius yang diterapkan di SMA Negeri 2 Sijunjung, yang dikumpulkan dalam kelas masing-masing, sebagai wujud dari sifat dermawan dan jiwa sosial. Manajemen kepala sekolah dalam menerapkannya yaitu: melalui ketauladanan, pembiasaan, pemberian nasehat, dan melalui Peringatan Hari Besar Islam (PHBI).

\section{Saran}

Berdasarkan hasil penelitian dan analisis di bab sebelumnya, peneliti perlu memberikan beberapa saran:

54 | Jurnal al-Fikrah, Vol. VI, No. 1 Januari-Juni 2018
1. Kepala sekolah, guru dan tenaga kependidikan di SMA Negeri 2 Sijunjung diharapkan untuk selalu menjalan program keagamaan yang telah direncanakan serta di aplikasikan dalam lingkungan sekolah dan masyarakat.

2. Siswa hendaknya selalu mendalami pelajaran agama dan umum, dan diharapkan siswa mampu melaksanakan dalam kehidupan sehari-hari di lingkungan sekolah dan masyarakat.

\section{KEPUSTAKAANACUAN}

Departemen Agama RI, (2007), Al-Qur'an dan Tafsimya, Jakarta: DIPA Bagian Litbang

Hasibuan, (2006), Manajemen Sumber Daya Manusia, Jakarta: PT. Bumi Aksara

Lexi J Moleong, (2002), Metodologi Penelitian Kualitatif, Bandung: Remaja Rosdakarya.

Sahlan Asmaun, (2012), Religiusitas Perguruan Tinggi, Malang: UIN-Maliki Press.

Suharsimi Arikunto (2010), Prosedur Penelitian Suatu Pendekatan Praktik, Jakarta: PT. Rineka Cipta.

Sugiyono, (2012), Memahami Penelitian Kualitatif, Bandung : Alfabeta.

Undang-Undang Republik Indonesia Nomor 20 Tahun 2003, (2006) Tentang Sistem Pendidikan Nasional, Bandung: Perman.

Usman Husaini, (2008), Manajemen (Teori Praktik dan Riset Pendidikan), Jakarta: Bumi Aksara.

Wahjosumidjo, (2011), Kepemimpinan Kepala Sekolah, Jakarta: PT Raja Grafindo Persada. 